6

\title{
L’assaig audiovisual com a procés d'exploració crítica. Indagació en les seues potències educatives
}

El ensayo audiovisual como proceso de exploración crítica. Indagación en sus potencias educativas

\section{The audiovisual essay as a critical exploration process.} Research into its educational powers

Vicente Barrachina Sánchez ${ }^{1}$

\section{RESUM}

L'assaig audiovisual com a forma visual i gènere crític, obert a la experiència creativa i a la captura del pensament en el seu desenvolupament, se'ns ofereix com un instrument plural i obert a la investigació i a la indagació dels entorns i les xarxes que ens constitueixen (en la seua vessant política, ideològica, social o cultural]. Creadors com Chris Marker, María Cañas, Andrés Duque o Pilar Monsell practiquen aquesta modalitat reflexiva i de pensament visual amb imatges, oferint exemples valuosos per a poder pensar en noves claus educatives amb caire marcadament crític. Aquest article tracta de indagar i identificar les potències educatives d'alguns dels assajos d'aquestos autors.

\section{PARAULES CLAU}

Assaig Audiovisual; Cultura Visual; Auto-reflexivitat; No-Ficció; Crítica

$1 \quad$ Universitat de València. Didàctica de l'expressió plàstica. Email: vibarsan@hotmail.es 


\section{RESUMEN}

El ensayo audiovisual como forma visual y género crítico, abierto a la experiencia creativa y la captura del pensamiento en su desarrollo, se nos ofrece como un instrumento plural y abierto a la investigación ya la indagación de los entornos y las redes que nos constituyen [en su vertiente política, ideológica, social o cultural). Creadores como Chris Marker, María Cañas, Andrés Duque o Pilar Monsell practican esta modalidad reflexiva y de pensamiento visual con imágenes, ofreciendo ejemplos valiosos para poder pensar en nuevas claves educativas con carácter marcadamente crítico. Este artículo trata de indagar e identificar las potencias educativas de algunos de los ensayos de estos autores.

\section{PALABRAS ClAVE}

Ensayo audiovisual; Cultura visual; Autorreflexibilidad; No-ficción; Crítica

\section{ABSTRACT}

The audiovisual essay as a visual form and critical genre, open to creative experience and the capture of thought in its development, is offered as a plural instrument and open to research and inquiry into the environments and networks that constitute us (in its political, ideological, social or cultural side). Creators such as Chris Marker, MaríaCañas, Andrés Duque or PilarMonsell practice this reflexive and visual thinking modality with images, offering valuable examples to be able to think of new educational keys with a markedly critical character. This article tries to investigate and identify the educational powers of some of the essays of these authors.

\section{KEYWORDS}

Audiovisual essay; Visual culture; Self-reflection; Non-fiction; Critic approach

\section{INTRODUCCIÓ}

L'assaig audiovisual és un objecte sense gènere. Una espècie polimorfa, híbrida i mutant de contorns imprecisos i en constant transformació. Una forma que continua la tradició de l'assaig literari i filosòfic, exercida àmpliament per alguns pensadors com Michel de Montaigne al S.XVI i altres escriptors estudiosos de la cultura com D. Diderot, W. Thoreau, H. Arendt, T. Adorno, G. Lukáks, W. Benjamin, o V. Woolf. Es tracta d'una manera de procedir, subjectiva, conscient, i reflexiva sobre un tema d'indagació. Un teixit de relacions entre idees, conceptes i imatges. Com a forma de reivindicació de la individualitat, i a partir de la seu procedir crític, des de la literatura i la filosofia, troba, amb el sorgiment de les formes narratives cinematogràfiques, un espai a la pràctica de les imatges en moviment. Entés també com a escriptura amb imatges, l'assaig obri un espai que des del documental s'expandix cap a altres dispositius retòrics i maneres de fer [pròpies de la ficció i d'altres pràctiques experimentals], posant en crisi les taxonomies tradicionals de la institució teòrico-pràctica del cine i les fronteres entre gèneres i les disciplines. 
Es tracta d'una modalitat artística i crítica en la que el cineasta, en un exercici de compromís i activitat, queda implicat en les traces de la seues imatges, investigant el món, posant el valor en la intuició, la memòria i la pròpia experiència per tal de produir pensament des d'una mirada sensible i atenta, qualitativament política, íntima i educativa.

No ho neguem: Vivim amb imatges i des de les imatges. Ens poblen, ens habiten. Són un factor configurador d'imaginari. La presència progressiva i ubiqua de tecnologies de la informació i de la imatge, els usos de les xarxes socials i les pantalles de consum i producció de textos fomenten la participació com a agents actius implicats en els processos de consum, publicitat o treball complex, el que ha generat una situació d'enorme interés i ambiguitat. La irrupció de les imatges com a fluxes i agents socials, d'intercambi en la societat de l'espectacle i l'esfera pública com a condició contemporànea capital que fabrica anclatges, posicionaments i processos de subjectivació (des dels quals establim models de relació] ha suposat l'emergència de nous paradigmes socials, culturals, institucionals i educatius. La superació de vells esquemes d'ensenyament estancs, de nocions disciplinàries així com l'expansió de l'art com a terreny d'exploració interdisciplinar són manifestacions que han obert possibilitats creatives considerant la importància de l'entorn visual i la interacció amb allò quotidià. Amb allò que ens envolta generant models, enfocs i perspectives de l'educació, de l'art i de la cultura amb àmplia capacitat de diàleg entre elles. Però no sempre és evident.

És condició necessària distanciar-nos críticament d'allò que s'ens presenta de manera inmediata com a consumible, mirar els ritmes i les fatigues del mercat, de l'imperi de l'actualitat com diu el filòsof Josep MaEsquirol [2016], per tal d'obrir espais de pensament i de pràctica creativa. Per comprendre-les en curs creatiu i fer-nos-les pròpies, per al creixement individual i col.lectiu.

Aquestos espais de pensament, d'alteritat radical, com senyala el cineasta i transmissor del cine Alain Bergala [2007], no sempre són accesibles en un món a sovint apressurat i acostumat a pràctiques de instrumentalització i racionalització dels temps dels quals els espais acadèmics i educatius no en són, malauradament aliens. És tasca necessària trobar espais o recursos per aprendre a decidir com implicar-nos, com resistir en la complexa societat postideològica en la que treballem, pensem, ens relacionem i vivim.

\section{MARC TEÒRIC. OBJECTE DE L'ESTUDI}

\subsection{Una polèmica : On és el perill?}

La utilització de l'assaig com a gènere literari i com a forma, ha estat objecte de complexes polèmiques i controvèrsies als àmbits acadèmics. Partint dels comentaris dels filòsofs T. Adorno i G. Lukáks trobem que els conflictes en torn a l'assaig han estat originats en gran mesura per un oblit constitutiu, originari, de la ciència: una escletxa entre art i ciència.

Tal i com pensa Adorno [1962]: "L'assaig pensa discontínuament, així com la realitatés discontínua, i troba la seua realitat a través de les ruptures, no tractant de tapar-les"² [p. 27]. El filòsof Giorgio

2 Traduccio de l'autor. Tots els textos citats al l'article es traduiran al Valencià per decisio de l'autor. 
Agamben, explica la condició crítica de l'assaig des de la clàssica fissura entre ciència i art, de tal manera que si el coneixement discursiu es troba amb la veritat sense disfresses, però és incapaç de gaudir-la, el coneixement que és l'art la posseix, però li resulta inconmensurable [Cuesta, 2009]. Altra de les particularitats de la forma assaig es manifestaria en la tensió present entre imatge i concepte. Entre l'atenció a la forma artística, als aspectes poètics o lingüístics, texturals... i la finalitat, la intenció científica de poder exposar una indagació, un coneixement segons uns codis suposats o convinguts com a objectius. L'assaig habitaria un interstici, com a forma de no anticipar-se en el sistema. Una modalitat de salvació del pensament singular, que presenta la problemàtica de conceptualitzar allò real sense clivells. Una manera de procedir crítica que, conscient dels conflictes de la reconciliació art-ciència, del dualisme d'una conciència que coneix però no posseix i d'una que posseix sense conéixer, a la vegada és concient de la seua pròpia contingència, de la inaccesibilitat. Com a aspiració a la veritat, però que, de camí, es troba amb la vida, en paraules de Adorno [1962):

\begin{abstract}
L'assaig es caracteritza per eixa manera de lliscar entre dos mons -ciència i art- que adquireix valor i potència, precisament, al seu recorregut. Què fa l'assaig si no és rondar la forma de la que es serveix per començar novament el procés de donar forma? L'assaig apareix, com a forma estètica sense resolució, que només existeix en els camins que traça i no en les metes a les que arriba. És el seu caminar el que li dona valor, és en el recorregut on el lector es fascina amb la seua riquesa. [p.4]
\end{abstract}

El text de l'assaig, com a tal, manifesta la consciència del pensament, i per tant, podriem dir, metafòricament que pensa, evidenciant i donant forma i cos als mateixos processos d'escriptura, de relació i vincle d'idees, al seu caràcter processual, vivencial i ininterromput, obert i sense fi, amb la presència de contradiccións, de desplaçaments, de tensions, de pauses i amb la possibilitat de revisitar i tornar a aspectes de l'experiència ja existents.

Potencialment, l'assaig no sabria negar les seues ocultacions ni tampoc ocultar-ne les influències. Si bé recrea la forma i la pensa, la força de la seua acció radica, precisament en que en l'assaig, la meta és la crítica. Com una pura instància crítica. Un espai de llibertat, des d'on pensar, sabentse contingent, conscient de les condicions d'inaccesibilitat a allò universal, a la veritat, a la vegada que tracta de matissar les aproximacions als objectes d'estudi. Adorno [1998] citat per Cuesta [2009):

"Per això s'estigmatitza com a cosa ociosa l'esforç del subjecte a l'assaig per penetrar el que s'amaga com a objectivitat darrera de la façana: se l'estigmatitza com a pura por a la negativitat". [p.247, p.5 de l'article]. A l'assaig, la intuició es considera el principal òrgan de coneixement. Permet el contacte directe con els trets específics del viure [Cuesta, 2009].

L'assaig partixd'allòméscomplexe, desmarcant-seaixí, delideal clara etdistinctia perceptiocartesià, constitutiu del discurs del mètode, segons els quals s'hauria de procedir argumentativament des d'unitats més simples d'anàlisi en complexitat creixent.

Cineastes com J. L. Godard, Agnès Vardà, com Alain Resnais, Chris Marker a França , Johan van der Keuken a Holanda, Pier Paolo Pasolini a Italia, Robert Kramer als Estats Units, Patricio Guzmán a Colombia o Glauber Rocha al Brasil, buscaren un paper més implicatiu per al cinema, indagaren en el llenguatge per tractar d'innovar. Partint de la sensibilitat documental i de les seues possibilitats creatives i també pensatives, alguns van fer pedagogia i crítica de la cultura, de la massificació de les imatges, altres tractaren de recuperar la vocació perduda del cine 
com a generador de coneixement entre la filosofía, la literatura i la ciència. Altres projectes es dirigiren cap a els espais marginals per documentar contextos i processos de marginalització política, i aportar la seua part d'acció i de proposta per a un món en trànsit, convuls i en procés d'efervescència social i cultural. Tots inventen noves formes, noves possibilitats de relacionar-nos amb les imatges, de documentar i treballar amb allò real, les tecnologies de la imatge i el món des d'una perspectiva singular, contingent, irreductiblement vital.

\subsection{Sobre la problemàtica de l'adscripció genèrica de l'assaig.}

Si fem un rastreig dels origens de la noció historiogràfica del film-assaig, de les publicacions, retrospectives, i mostres importants dels anys noranta i principis de la dècada de segle XXI, es constata que la dificultat d'adscripció genèrica d'aquesta pràctica és, (en l'escenari crític de disgregació de gèneres, disciplines expandides i creuament de fronteres] més bé una dificultat d'adscripció institucional [Weinrichter, 2007), a causa de la multiplicitat de camps i de disciplines que es creuen en les pràctiques dels assagistes, donant espais a interessants mestissatges.

$\mathrm{Hi}$ han cineastes als quals s'els pot aplicar la categoria d'assagistes, i en els treballs dels quals s'aprecien diferents camps d'acció en el marc de la institució-cine: Cine de ficció [Godard, Welles, Pasolini], Cine experimental [Mekas] o Cine documental (Haroun Farocki, Chris Marker]. No obstant no va ser fins els anys 80 que la presència d'una forma en vies de consolidació va començar a cristalitzar.

Podem pensar, juntament amb Weinrichter que l'orige de l'assaig fílmic és una expansió de la imatge factual [Weinrichter, 2007], és a dir, del documental, que hauria quedat discursivament excedit per noves aproximacions des d'altres disciplines, des d'altres camps intitucionals: de la narrativa de ficció, el cine d'avantgarda i les pràctiques audiovisuals artístiques ${ }^{3}$.

El que podria semblar una sorprenent mancança d'espai institucional no deixa de ser ser revelador d'una pràctica que inventa la seua pròpia forma, el tema i inclòs el seu propi referent [Weinrichter, 2007]. S'ha parlat de l'assaig com a culminació del documental, com a pràctica de L'Etnografia experimental [en Catherine Rusell], o com a Ur-forma, segons Nora Alter, prenent una noció de Reda Bensmaïa ${ }^{4}$ ], és a dir, com a forma reprimida d'altres gèneres [Weinrichter, 2007] i com a retorn a la seua vocació o horitzó tendencial de generar coneixement.

Nicole Brénez, d'altra banda, parla de quatre dimensions (argumentativa, històrica, formal i estètica] i Christina Scherer dels aspectes estratègics pel quals podem identificar trets de les pràctiques assagístiques. Segons ella són els següents: 1. La visió subjectiva [onírica, imaginativa, memorial]. 2. La posada en dubte de la representació de la realitat (indecisió de la veu]. 3. No linealitat, fragmentarietat. 4. Hibridació i heterogeneitat de formes i materials significants.

També podriem valorar d'altres nocions proposades per acotar-lo terminològicament: noció potencial [Weinrichter, 2007], voluntat d'assajar [Font,2007) o el professor J.Ma Català, que

\section{$3 \quad$ ibid. pàg.23}

$4 \quad$ El text en questió és The Barthes effect: The essay as a reflective text. Referenciat en Un concepto fugitivo, notas sobre el film ensayo. En La forma que piensa. Tentativas en torno al cine ensayo. [Pàg. 48). 
pensa més en una necessitat d'obertura, creativitat i pluralitat originada en una convicció de la multiplicitat tonal de la realitat.

L’assaig seria la veu i la pràctica d'aquesta necessitat.

Amb aquestes observadores notes podem parlar, ja no d'intentar trobar una definició taxonòmica vàlida per a aquesta espècie polimorfa, híbrida i en constant transformació, sino més bé una col. lecció de condicions per a una manera de procedir oberta, creativa, plural : 1. Hem parlat de imatges factuals expandides que han superat la noció tradicional de documental ${ }^{5}$ (Weinrichter]; 2. De visió subjectiva [Scherer]; 3. Autorreflexió [Alter] i també podriem pensar en una quarta: Una certa mirada distant, de segon grau, que ens permet tornar a mirar les imatges com si no foren únicament objecte de fascinació (Weinrichter, 2007).

\subsection{Possibilitats de l'assaig. Què és el que contempla el currículum?}

Els continguts del currículum de 1r de Batxillerat proposat per la Llei Orgànica per a la Millora de la Qualitat Educativa [LOMQE] de 2013, contemplen la possibilitat de tenir una trobada amb el cine, l'audiovisual i la cultura narrativa amb imatges en moviment.

Al currículum de l'assignatura Cultura Audiovisual (en el DOGV), on es troba la formalització i la programació de continguts, objectius, competències clau i criteris d'avaluació de l'assignatura trobem indicacions per tal que l'alumnat puga llegir i comprendre el missatge dels productes audiovisuals, expressar-se amb imatges i utilitzar diversos recursos per generar missatges creatius. [DECRET 87/2015, DOGV de 5 de juny de 2015, Annex.1]

Donat el repàs historiogràfic per la forma-assaig, és moment d'assenyalar alguns dels diversos aspectes interessants que trobem com a factors educatius presents a l'exercici de l'assaig audiovisual:

1. És una proposta de reflexió basada en l'autoconsciència, per tant, és una activitat que fomenta el pensament crític, tant individual com col.lectiu.

2. Permet apropar-nos de manera artística a aspectes de la vida social, política, cultural.

3. Com a tal, l'art no només funciona com a documentador, com a arxiu viu de l'entorn, sino com a catalitzador dels processsos de transformació del cineasta o l'alumne, queden desplegades per al dispositiu.

4. Com a eina sustancialment heterogènia admet tot tipus de propostes col.laboratives, convertint-se en un bon motiu de treball atentent als aspectes semàntics, relacionals, interpretatius d'un equip de treball.

$5 \quad$ Weinrichter fa un repàs a la història de les publicacions que tractaren de realitzar una aproximació a la conceptualització de l'assaig: 1997 amb la retrospectiva Fake; 2000 al Centre Pompopidou de Silvie Astric, Le filméssai: La identification d'un genre; l'any 2003 amb Berta Sichel i la mostra postvérité; l'any 2002 amb Ursula Bieman i la retrospectiva Stuff it i en 2005 amb l'essai filmé. Encara que hi han textos relevants com l'Antologia de Christa Blümlinger i Constantin Wulff [1992] o el de Phillip Lopate, de 1996. 
5. També és un motiu i un mitjà per a poder atendre a l'entorn més inmediat, als context sociofamiliar, afectiu, a la casa, a la ciutat, obert al treball per projectes del treball per projectes.

\section{OBJECTIUS: QÜESTIÓ D’INVESTIGACIÓ}

En el marc d'un paradigma contemporani i d'epistemologies en crisi [J.M.Català, 2014], ja no és sensat emprar premises i principis extrapol.lables que s'abstraguen de la societat complexa en la que vivim. En qualsevol cas, no ho podriem fer sense ser conscients de que formen part d'un teixit i procés vivencial. Els estudiosos del models formatius han exposat en els seus treballs diverses maneres de pensar la presència, la funció i les propietats de l'art en l'àmbit educatiu. Tenint en compte l'afinitat amb el model pragmatista, que assumeix la interacció de la experiència estètica i la continuitat amb la realitat vital de l'alumnat com a horitzó educatiu i com un condensat de creences, valors i de significats [Aguirre, 2006), però considerant l'enfoc cultural, ambiental, contextual i crític de la Cultura Visual present a les noves perspectives de investigació en l'arts en l'era de la imatge en la que vivim [Hernández, 1997), l'objectiu central d'aquest treball, es definix per tractar d'esbrinar algunes potències i propietats educatives implícites a la pràctica d'assajos audiovisuals, utilitzant una metodologia pròpiament assagística, és a dir permetint la emergència d'una escriptura crítica de traça creativa i experiencial.

\section{DESENVOLUPAMENT DE L'ESTUDI.}

\subsection{La cerimònia de la visió. Sans Soleil [1983], de Chris Marker}

El Japó i Cap Vert poden ser dos pols oposats de supervivència en contrast amb la civilització occidental. Potser, alli sobrevisquen certes formes de comportament, que hi hagen certs atributs rituals que poden ser un motiu d'indagació, potser siga una voluntat de veure, de desitjar. Són una hipòtesi de partida que en aquest cas impulsa un afecte creatiu. Un viatge. L'assaig sempre inventa un recorregut per tal de confessar-nos un secret.

Una imatge de la felicitat, gent dormida a un vaixell camí a Tòquio, evocacions de guerra de paisatge postbèlic, la potència en el rostre d'una dona a Guinea, la memòria del colonialisme portugués. El valor de la bellesa d'allò quotidià, la voluntat de mostrar allò senzill, llegendes amb animals mediadors al Japó, rituals amb sake als cementeris, emús a França, joves atrapats als videojocs, tribus urbanes com a bebés marcians, takenokos, oradors carismàtics d'altres temps...

L'assagista com a indagador en un traçat que partix de la mirada documental, cultural, per poder trobar resposta a interrogants artístics, creatius, i humans. Un sacseig d'anades i tornades. Un traçat d'imatges que, transversalitzades per una mirada atenta, àmplia i múltiple, operen per posar de manifest interrogants constants en l'ofici de fer imatges. Les agudes observacions tracten, no només de detindre's en els espais, en la gent, en allò que troba extranyment estètic, sino de reflexionar amb profunditat, crítica i perspicàcia sobre una preocupació primordial en forma interrogant: Cóm es fabrica la memòria? que podria remetre a un aforisme atrevit, impulsor de la creativitat: Tot assaig és una fàbrica de mirada.

Sans Soleil és un exercici assagístic ple. Parteix de la condició viatgera d’un emisor, Sandor 
Krasna, que envia cartes sobre l'arribada, les estades, reflexions i indagacions al voltant de les geografies que va visitant, dels paissatges en els que participa, i de les sensacions que les pràctiques culturals, els rituals, les situacions quotidianes i les imatges que emergen de cada context li susciten. Les imatges també poden ser cartes.

Hi ha una veu femenina que llig les cartes que Sandor li envia [moltes vegades començant per "ell m'ha escrit:"] A partir d'aquesta lectura, l'assaig posa en questió, informa, comenta i fricciona les imatges que flueixen, posant de manifest l'exercici que caracteritza a la generació de la mirada de segon grau pròpia de la condició assagística. Una veu, per tornar a mirar, per veure, per saber, que no resta potencial a les imatges, ni les supedita a la verbalitat, sino que les fricciona, reconduint el seu potencial.

Que la força de l'assaig siga la de la dansa fràgil i lluminosa de la memòria es posa de manifest al recorregut i les relacions mentals que s' elaboren al discurs de qui escriu, a la veu de qui llig i les imatges que vem.

La mirada històrico-crítica de Marker, amb elements autobiogràfics, es combina la mirada etnogràfica amb enfoc poètic, posant especil ènfasi en els costums, les maneres de fer, dir i les pràctiques culturals contemporànies que ens presenten als diferents contextos culturals, utilitzant imatges documentals que són expandides pels comentaris de la veu, que friccionen amb textos de llenguatge el.laborat, irònic, poètic, concís, i aforístic.

Sans Soleil evidència les imatges com a eina antropològica, però l'aproximació antropològica com a recurs per a poder pensar la imatge, i la fascinació per les imatges, l'art, la memòria i els processos perceptius i d'atenció. La radicalitat de la seua mirada humana, crítica i lírica guiada per la perseverància de l'interrogant per la memòria l'impulsa a preguntar-se en un encadenament cultural i etnogràfic d'imatges sobre allò que subsisteix en les mirades [figs. 1-6]. ${ }^{6}$

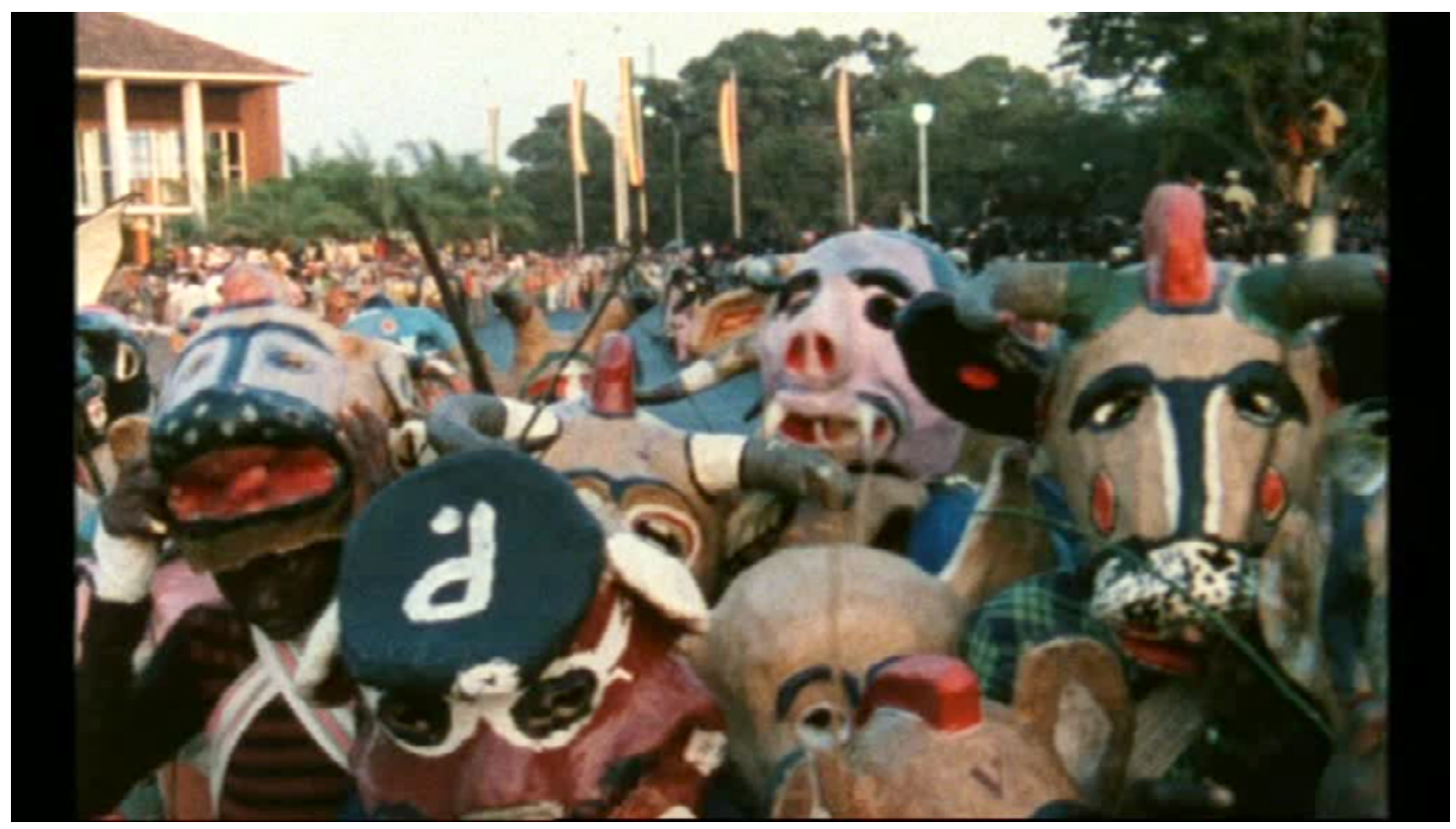

FIG.1 Sabem alguna vegada on es fa la història?

$6 \quad$ Figs. 1-12. Captures de frame de Sans Soleil [1982], de Chris Marker. 


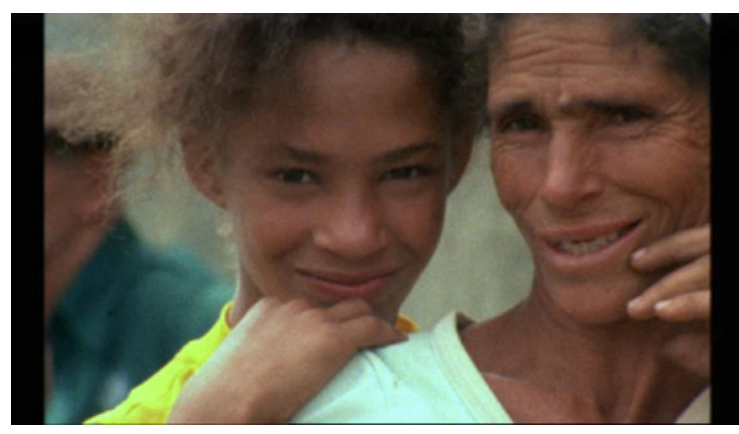

FIG.2

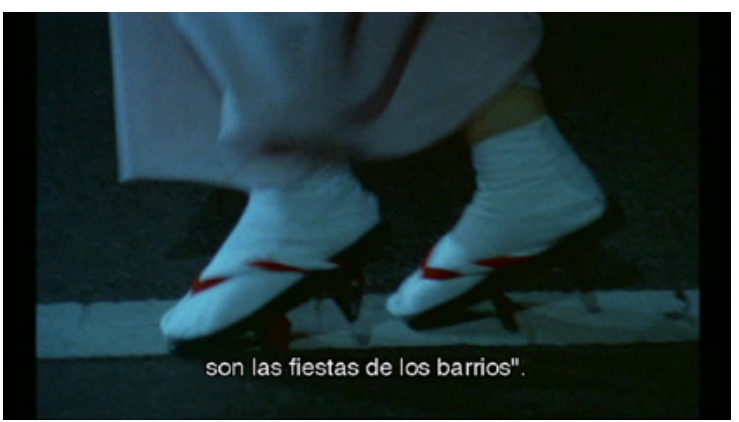

FIG.3

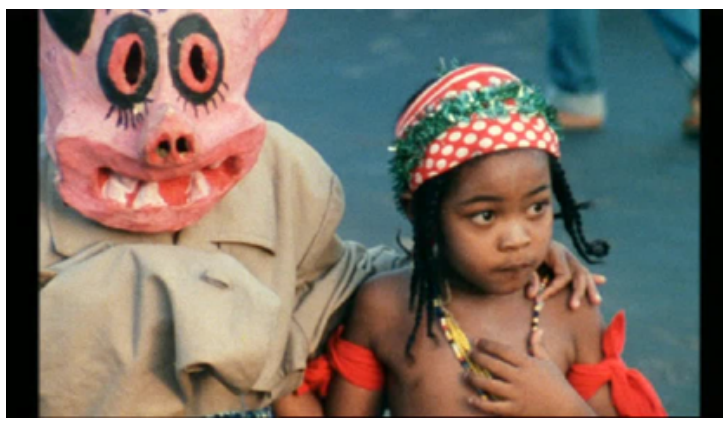

FIG.4

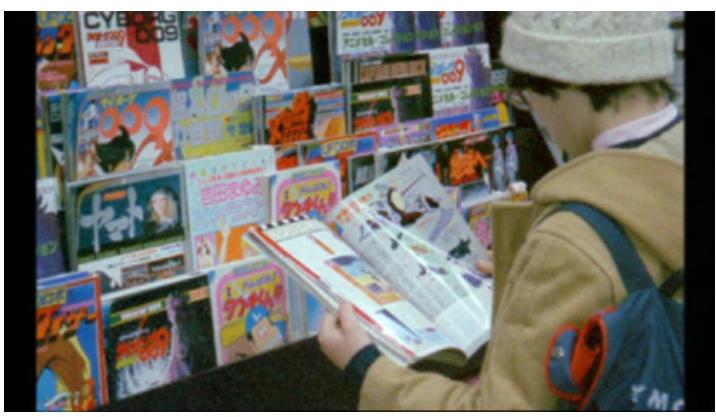

FIG.5

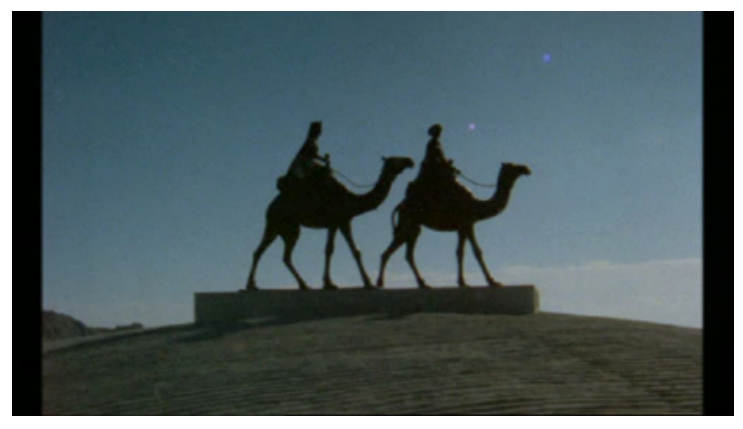

FIG.6
Un del aspectes més operatius de la seua mirada múltiple, és, la possibilitat crítica d'assumir els grans relats (el vell personatge japonés orador carismàtic i intempestiu, les reflexions sobre el procomunisme i anticomunisme que travessen les seues estades a Japó i a Guinea i Cap Verd] com a narrativa contingent, contemporanis de relats i rituals antics [balls i música amb disfresses d'animals a Guinea, temples dels gats al Japó, plegàries als carrers, sake als cementeris, la dama Sei Shonagon, el gos Hatchiko, els balls i les festes dels barris, la lectura en els carrers...] i noves pràctiques cerimonials [objectes del vaticà exposats en una sala de uns gran magatzems a Tòquio, espais decorats amb fals escultòrics, tribus urbanes reunides per ballar, pintures als murs...) utilitzant la seua visió cerimonial com a una mirada transversal a la història, que es pot presentar com a memòria, entesa com a matèria d'art, en una lectura sempre des del present.

En aquest cas, l'assaig inventa una manera de fer memòria. Marker, específicament, tracta de proposar lectures de les imatges del passat, pensant-les, interpretant-les, per establir nous horitzons per a la memòria. Per a la constatar la pervivència de formes passades en les formes actuals i pràctiques presents, per constatar les erosions, les diferències, les evolucions i les resistències, manufacturant un discurs sobre la memòria entesa no com a contenidor, sino com a acció, com a fàbrica imaginal. Com a cosa sempre per fer, i per tant com a horitzó ètic i de creativitat responsable. L'assaig audiovisual pot ser una eina per fer conscient la necessitat de que aquesta funció crítica i creativa no passe desapercebuda. Una manera de mantindre encesa l'espurna de la visió i la curiositat per la humanitat amb els seus vicis i els seus desitjos més nobles.

Interrogants com: Confiem en les imatges? Creiem en els nostres ulls? Quèvol dir confiar en la pròpia mirada? Què és mirar? son preguntes consubstancials a la operació inquieta d'assajar amb imatges.

Es tracta d'entrenar la curiositat posant en pràctica una mirada que no s'esgote, sempre inabarcada, per mantenir el tarannà crític, per poder donar-nos espai íntim, on puga crèixer la confiança, la organització del propi món i la comprensió profunda de l'experiència. 

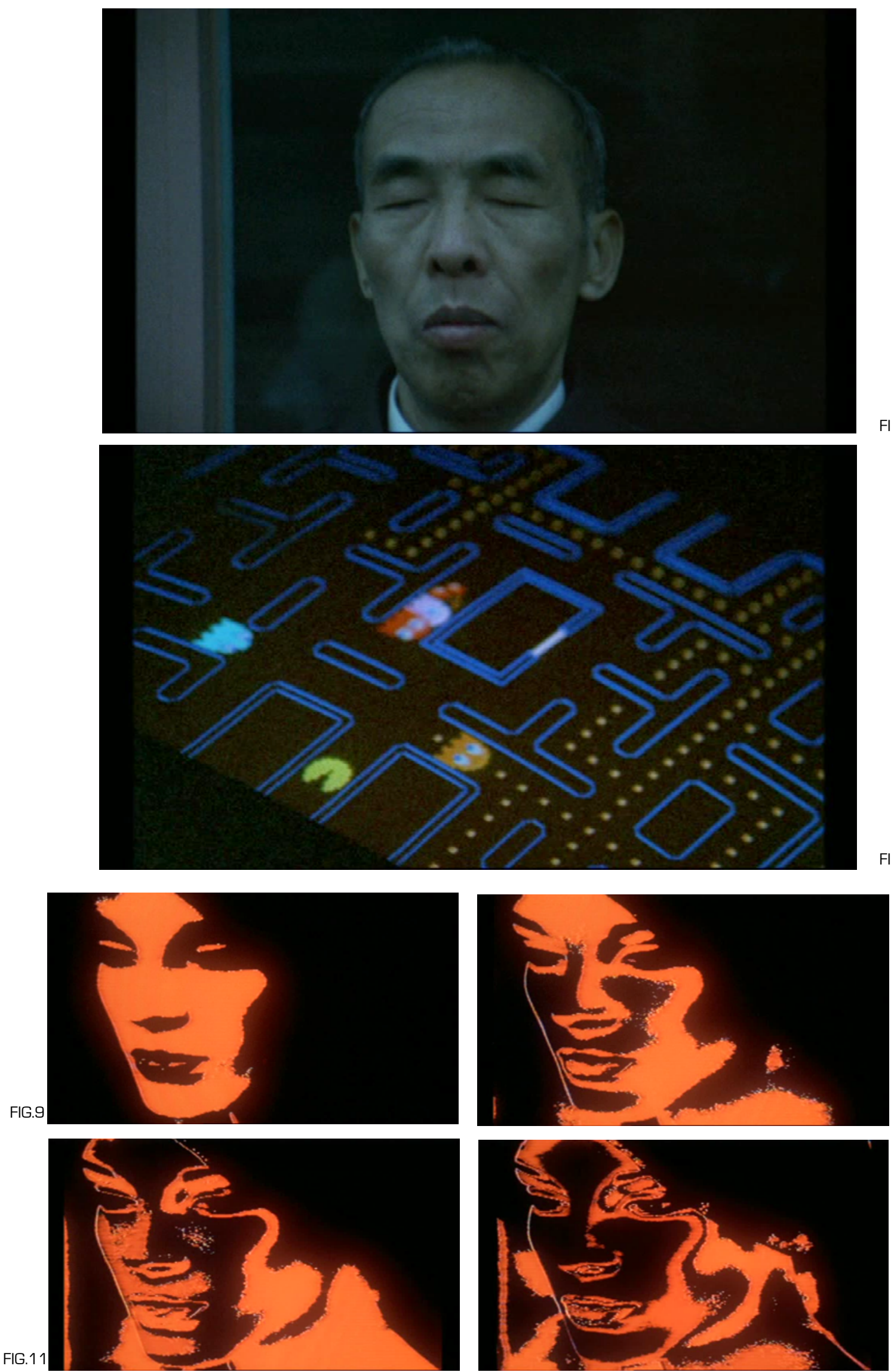

FIG.12

La imatge ja no és la forma transportable i compacta d'una realitat inaccesible 


\subsection{Intel.ligència íntima. África 815 (2014], de Pilar Monsell.}

Un vaixell, en moviment per la mar, horitzonal a la pantalla. I sentim a la cineasta demanant-li a son pare que li parle del que ha somiat la nit anterior. Sentim, però no vem. Li parla d'una ciutat destruida, i li fa saber que podria ser Barcelona, però no ho té clar, Les imatges són imprecises... és un escenari apocalíptc, bèl.lic, semblant a un de guerra. I ell la busca. Vacil.la, balbuceja. Conclou que racionalitzar allò que somiem és una tasca difícilment factible.

Ací són les paraules, les escrites i les llegides, les pronunciades, les que incorporen, amb el cos de la veu i el cos de l'arxiu un discurs sobre la curiositat, la passió i la il.lusió per viure enamorat. L'autora parteix de les memòries escrites de son pare, el metge Manuel Monsell. El punt de partida és una sèrie de fotografies de l'arxiu familiar i pel.lícules amateurs domèstiques i de viatges rodades per son pare. Des d'aquestos materials, la veu de la cineasta ens proposa un viatge per la història sentimental de son pare, des de que va partir "cridat" com a militar al Sàhara. Però no només és acò.

Des d'una mirada microhistòrica i etnogràfica i amb un enfoc autobiogràfic, la cineasta proposa diverses accions que a la vegada configuren un relat de la generositat i la franquesa. Utilitza alguns segments de les memòries escrites pel pare [organitzades en diversos toms: La vida en rosa i La babucha amarilla] per poder comentar algunes de les imatges d'aquella època, alguns dels moments més importants en la vida de son pare a partir de l'arxiu, mentres desfilen les imatges fotogràfiques que fan visible la seua estada, els paissatges desèrtics i l'entorn convivencial als campaments.

El nous paradigmes artístics i els models discursius dels últims anys han posat de manifest la crisi de les representacions de la realitat, la interdisciplinaritat i l'ampli camp de interfluències en el que l'art ha deixat de ser, merament, una forma autònoma per ser atravessat per múltiples vectors investigadors i de mediació. Entre aquestos salts i canvis de perspectiva es fa necessari llegir [entés com a interpretar] imatges com a símptomes en termes de les questions socials a les que es vinculen [Giroux, 1996]. Partint de la facticitat del documental d'arxiu, aviat ens adonem de la voluntat assagística del treball. En la fricció de les imatges fotogràfiques i allò que la veu diu, la matèria vocal, hi ha una aventura literària i creativa que sembla extraure de la potencial força de les fotografies, possibilitats d'expansió cap a territoris més literaris, pictòrics o inclós de la ciència ficció, alliberant potències de la imatge. Un exemple: vem el cap del pare, una bandera de l'estat espanyol dalt d'un edifici i la veu pronuncia la paraula "companyerisme". La veu, el discurs, posa en pràctica una estratègia creativa per generar reflexions i pensar els símbols assumits en l'imaginari social, cultural [com ho és una bandera], o també establint espais poètics que ens recorden a la retòrica de la fantasia o la ciència ficció, amb atmòsferes inquietants i evocadores: el desert, la vida de les dunes, les granades i els llits del riu. Aquesta manera de procedir amplia l'arxiu, recreant-lo i ens situa en un altre topos potencial de l'assaig com a productor de formes polítiques, socials i ètiques: treballant des d'allò personal, s'obté un subtil balanç de les figures mítiques, del viatger i proposa una interessant reflexió des de l'imaginari del romanticisme i l'exotisme colonials i de les figures aventureres de fàbules i llegendes.

L'art pot entendre's com a procés de significació, de subjectivació i de configuració de identitats en el que valor polític de la pròpia narrativa biogràfica, es transforma en un dispositiu cultural ampli, com una eina eficaçment simbòlica per a explorar. Els treballs artístics amb els imaginaris colonials, formen part d'aquest enfoc etnogràfic i també politic, crític. Pilar Monsell treballa des 
de la proximitat i l'estima, des de la voluntat de comprendre i mostrar un exemple. Aquesta voluntat de comprendre, com a tal, és una de les línies que orienten l'acte i el procés educatiu segons Hernández [1997):

La finalitat de l'ensenyament és promoure en els alumnes la comprensió del problemes que investigue. Comprendre és ser capaç d'anar més enllà de la informació donada, és poder reconéixer les diferents versions d'un fet, i buscar explicacions i plantejar hipòtesis sobre les conseqüències d'aquesta pluralitat de punts de vista. [p. 221].

L' autora no només es sap present a les memòries, sino que fabrica imatge per tal d'investigarse, per processar la seua història. També hi han moments de silenci verbal: On els avatars i de la vida del pare continuen en color, amb la textura del súper huit, imatges del dia de la boda, de les pel.lícules de la lluna de mel, amb la seua muller, i amb els diversos amants que tingué, reconeixent les seues pròpies febleses. El ritme de lectura, calibrat i acurat (hi han silencis que valoren la fluència pròpia de les imatges] faciliten assumir degudament la contundència d'algunes reflexions.

Aquest treball de reflexió sobre la intimitat i les potències dels arxius personals, evidència com amb estratègies creatives es poden generar les distàncies íntimes per poder veure, la intel. ligència per apropar-se als desitjos i a les decepcions amb els materials confessos que tenim a l'abast. Una manera de fer i de preguntar-se sobre las possibilitats de treballar una història sobre la valentia, la família, la diversitat i la lluita per ser feliç. De fer autoindagació diarística, i cultivar la intimitat com a forma de resistència. Organitzar la intimitat siga la noble funció d'atendre i tractar de comprendre imatges en les seues dimensions més implicatives [figs. 13-15]?.

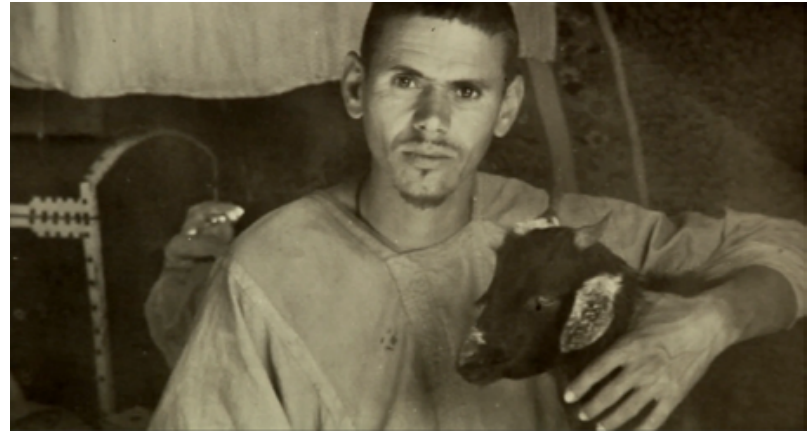

FIG.13

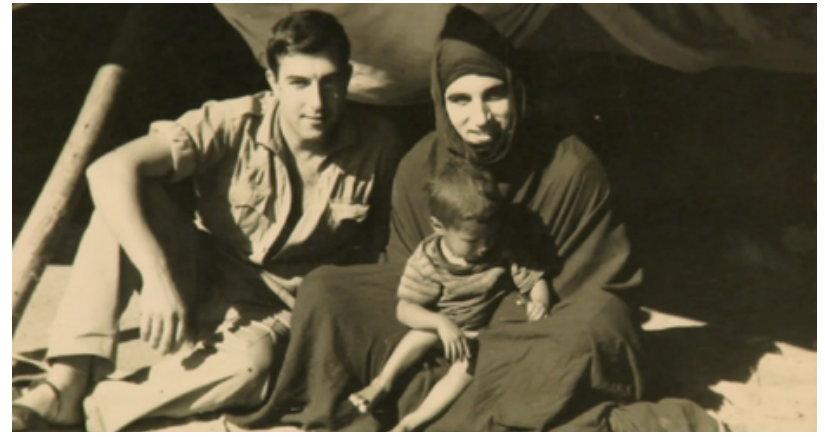

FIG.14

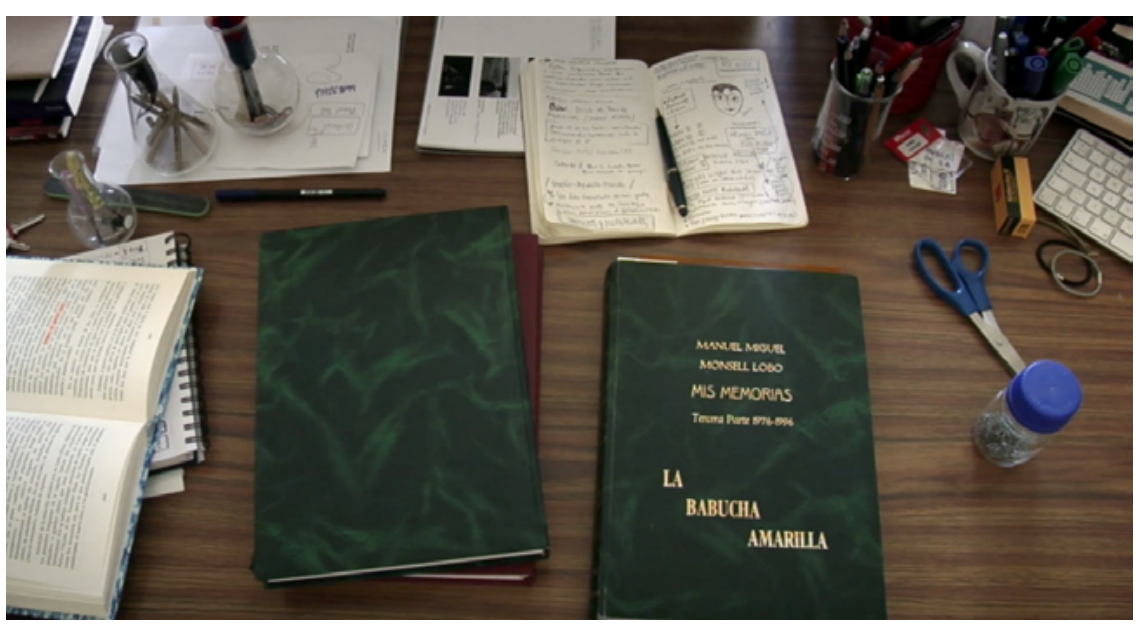

FIG.15

El material base, fràgil, subtil de la memòria

$7 \quad$ Captures de frame de Àfrica 815 [2014], de Pilar Monsell. 


\subsection{El reciclatge que pensa. Sé villana. La Sevilla del diablo [2003], de María Cañas.}

Coneguda com l'arxivera de Sevilla, i caníbal audiovisual, María Cañas practica una modalitat de la pedagogia crítica a l'àmbit de l'audiovisual hereva del agitprop i el culture jamming, de la remescla de materials ja elaborats. Desde un posicionament contracultural posa en pràctica l'estètica del fragment, reflexionant amb diferents estratègies de muntatge on el discurs s'estableix en el contacte entre fragments, com a agents considerats en tant que arxius, on el discurs de l'apropiació, la recreació de significat a partir de materials significants es sustenta en l'horitzó activista sobre la propietat, els drets d'autoria i les formes d'intervenció i participació social. Amb un enfoc celebradament crític i ecològic ens convida a utilitzar els materials ja presents a l'hàbitat iconogràfic, mediàtic, visual. Com si es tractara d'un cos o realitat fluida, complexa i histèrica, també vigilant. Ens convida al reciclatge.

Partint dels imaginaris populars autòctons, les tensions global-locals que participen els processos de subjectivació i de identitat, María Cañas proposa exercicis de gran potencial polític i de celebració cultural expandint la pràctica del collage a la selva audiovisual. Explora múltiples possibilitats de reconsideració de significats en les inmenses arenes de la xarxa digital. Un dels exemples on podem detectar aquestes potencialitats assagístiques, crítiques, ecològiques i lúdiques, que parteixen de significacions ben assentades des d'una cultura televisiva i rabiosament mediàtica és Sé villana [2003].

Figures andaluses de la fira d'abril, cantaors i cantaores pertanyents a ficcions cinematogràfiques, a documentals, programes on l'escenari evoca l'estètica dels cortijos i certes figuracions del masclisme, ballaors i ballaores en contextos d'espectacularització extrema... En el cas de María Cañas, outsider, es tracta de donar presència a figures monstruoses, marginals, i anònimes, capaces de fer visible un animalari de la diferència, i posar-lo en contrast amb les formes acostumades de la visibilitat mediàtica, per tal d'operar en la diferència, de fer dialèctica viva i d'assumir una manera de treballar i de fomentar propostes basades en l'ecologia visual, la contrainformació i les contracultures. La seua estètica del muntatge dels materials contempla la duresa d'evidenciar la heterogeneitat de materials i el camp de mestissatges de la cultura visual. Juga a la sorpresa, les transicions inesperades, sorprenents. La ironia és el motor per poder tractar les ferides de l'imaginaris més oblidats i marginals, i la mordacitat, per combatre les imposicions i l'estat de les coses mediàtic. La contingència, l'accident, l'error o la contradicció, des d'aquest punt de vista, es tornen creatius, com a potencial eina de crítica, també d'interactivitat:

\footnotetext{
front a la Cultura visual no hi ha receptors o lectors, sino constructors i intèrprets, en la mesura en que l'apropiació no és passiva ni dependent, sino interactiva i acord amb les experiències que cada individu ha experimentat fora de l'escola. D'ahí la importància, el lloc de pont que exerceix la cultura visual com a camp de sabers que permet conectar i relacionar per a comprendre i aprendre per a transferir l'univers visual de fora de l'escola (des de la video-consola, els vídeo-clips, les caràtules de CD, la publicitat i el ciber-espai]" [Hernández, 1997, p.161]
}

Un moviment de tremor, un sisme amb un dispositiu ampli, desenfadat, i celebratori que pensa els rituals autòctons de Sevilla i les formes culturals de devoció, atenent a allò que ens fascina perillosament, amb un enfoc crític, però irònic dirigit la crítica del fanatismes, a les industries, a les ingerències excesives del poder en la vida dels barris, apropant-se a les versions dels d'avall, $i$ donant visibilitat i imatge a les figures d'aflicció, desnonades i desamparades. 
FIG.16
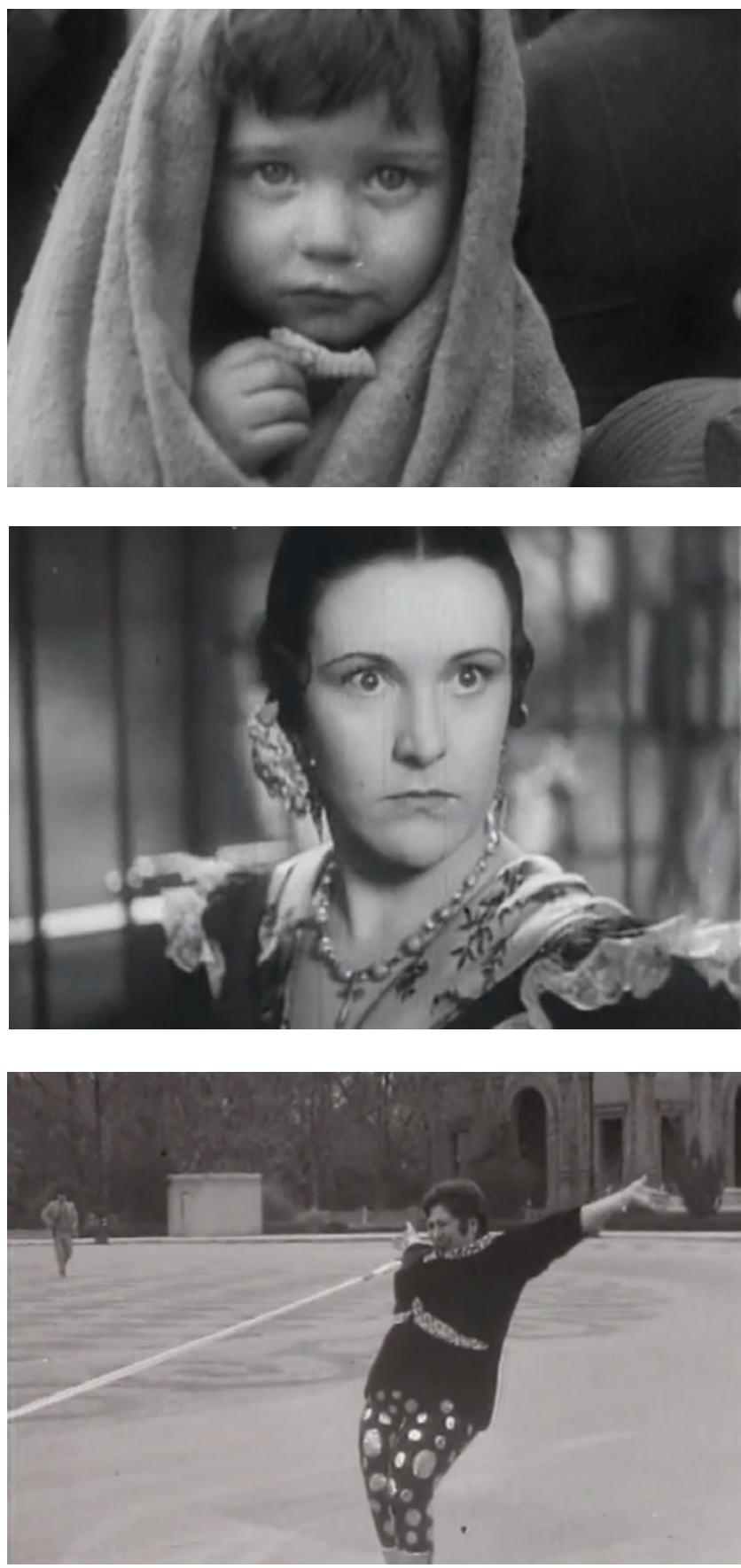

FIG.2O
FIG.17
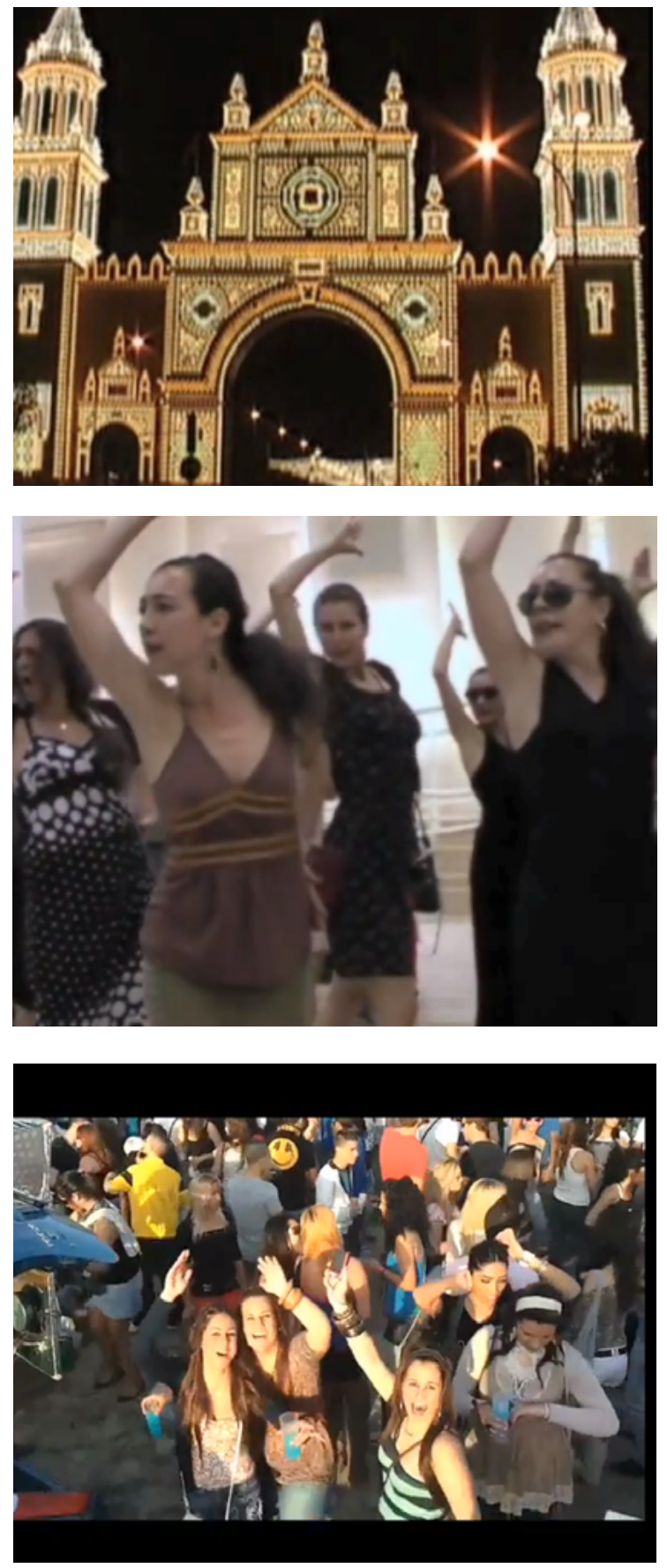

FIG.21

Sé Villana treballa el muntatge de les imatges com un poder de ser contactades les unes amb les altres, de contaminació recíproca de fragments per les voreres, de fregall amb tot tipus de detriuts. Els seus recursos d'apropiació per questionar els principis més assumits sobre els estereotips culturals, la identitat, i els relats del poder donen continuitat a la tradició crítica del pensament visual [figs 16-21] ${ }^{8}$.

8 Captures de frame de Sé Villana. La Sevilla del diablo [2003], de María Cañas. 


\subsection{Dress Rehearsal For Utopia [2012], de Andrés Duque.}

Dress rehearsal for utopia [2012] és un exercici diferent. Una mostra de les contínues influències del cine amb els terrenys experimentals de la imatge en moviment i del videoart, de la mirada etnogràfica i històrica sobre les ilusions, projectes i desig de llibertat d'un país. Tanmateix una aproximació des de la poesia i la lírica al diari íntim, i, a la vegada, una manera d'aprofundir en la vocació de generar coneixement, tornant-li al cine, com deia Godard, l'espai, "entre la filosofía, la ciència i la literatura" (Aidelman i De Lucas, 2010).

En aquest cas, d'autoindagació en allò vist, i de preparació per a allò que s'està vivint, com a búsqueda de la força i de l'energia.

El punt de partida d'aquest treball està a Moçambic, on el cineasta traballa en una pel.lícula, quan és avisat de que son pare, està a punt de morir i ha de tornar a Veneçuela. La búsqueda de la força, de la comprensió, i la teràpia son els motius del quals partir per organitzar les imatges. És curiós com es resol aquesta situació en la que l'artista, parteix d'aquesta situació afectivament conflictiva i desequilibrant per comprendre-la des del seu ofici de cineasta i confiar-li a les imatges un secret de les que elles són còmplices. Les imatges com a registre de l'experiència entre el diari fílmic, la meditació, el ritual i una pedagogia del dol.

Les primeres imatges en son reveladores: al cineasta sentat a una estança fosca, amb la cara il.luminada. Algú li pregunta si pot passar. Entra i li pregunta com està. L' altra persona vol saber per què està trist. En el moment en que va a respondre, desapareix el so, i progressivament sentim un so ambiental, càlid, l'orige del qual desconeixem. Mentrestant, el plà ha canviat: vem una ombra dansant i en moviment continu. Sabem que és l'ombra del company, però a la imatge l'ombra és una forma sense referent, és justament una ombra. Sabem que és la projecció d'algú que balla, però és l'ombra la que ens parla, la que ens mira, la que ens apel.la.

Duque confia el relat a la juxtaposició dels fragments enregistrats, en una experiència on seràn les imatges les que aniran determinant la pròpia articulació tonal i modulant, sense voler apropiar-se en cap moment de la sensació de l'espectador, amb voluntat d'obertura. Imatges documentals, evocadores i sugerents. Una operació lleument pictòrica, com a trama en una superfície frondosa i evanescent, quasi onírica.

Després del preàmbul, ens trobem les imatges d'un gos passejant al voltant d'un cercle del que sembla sal. Un cercle amb creus del que sembla un lloc de trànsit, de ritual. El gos passeja pel cercle, pels voltants de la platja, seguint alguna emprempta, algún estímul.

És el cos susceptible a l'estímul, sempre atent. Des d'ahí, a partir d'aquest moment, l'assaig inicia la búsqueda de l'energia per les imatges, per allò que les imatges enregistrades emanen. Per diferents materials i provinent de diferents fonts: arxius, imatges enregistrades amb mòbils, càmeres mini dv, súper 8 i d'altres que presenten diferents regímens i diversos estatuts: documental, ficcional, testimonial, recreatiu.... La imatge no sempre com a representació sino com a presència i agent. Un viatge pel cor textural i la profunditat de visualització de les imatges, per tal de comprendre l'anatomia de les sensacions.

No passa desapercebuda l'abundància d'imatges de balls, danses, rituals de documentals registrats a Moçambique, imatges històriques en color, en blanc i negre, de l'època de la 
revolució, als anys 70, on apareixen filmacions de rituals, altres documentals de projeccions cinematogràfiques, imatges de polítics i militars, de les revolucions constelades. Joves ballarines, en pasal.les, acompanyant a cantants, amb xiques posant, altres xiquets més joves, davant de la càmera del cineasta: uns ballant, altres mirant-se entre ells. Vem també performances explícites modulades amb gestos quotidians on es constata la mutabilitat del cos. La capacitat d'afectar i ser afectat.

A la vegada, també les imatges son consciència. Són corporalitat. Corporalitat sonora, musical, gràfica, pictòrica. Una colecció de moments de gran energia, potència, contoneig, ball i videoperformance en els que el moviment del cos, individual o colectiu, L'expressivitat present ens remet a la intel.ligència artística i corporal del cine. A la natura de l'actuació i dels personatges, però també tensa amb l'horitzó des d'on pivota el projecte i el procés de treball: la mort, la inmovilitat i la desaparició, que, com a tal, planteja una sèrie d'ambiguitats al cineasta, d'esperit atent i de certa orientalitat.

Les imatges d'arxiu, imatges revolució, de celebració, d'educació, d'altres quotidianes de distinta palpitació, ens proposen una sèrie de questions sobre el colonialisme, ètiques, estètiques i crítiques pròpies d'una mirada sincera i d'àmplia tesitura. Es tracta de mantenir l'equilibri en una situació complicada, però de curs creatiu, i plantejant una peça que respon, en el fons, a un interrogant pedagògic i de realitat educativa: Cóm un esdeveniment advers o radicalment disrruptiu pot vehicular-se creativament amb respostes artístiques?

\section{CONSIDERACIONS FINALS}

Aquest treball havia pres com a punt de partida un dilema pedagògic i institucional plantejat pel cineasta i pedagog Alain Bergala al seu text La Hipòtesis del cine [2007]. Segons l'autor, la tendència de la pedagogia del cine, és a dir sobre el cine i des del cine, corria el risc d'oblidar, en favor de les aproximacions pedagògiques al cine des del llenguatge [i les ciències de la informació i la comunicació] la necessària tasca d'abodar la creació, perquè l'educació en audiovisuals puguera esdevenir una veritable experiència artística.

En aquest sentit, posar en valor les activitats de colecitus i associacions com a $A$ bao $A$ Qu, amb Núria Aidelman i Laia Colell i els projectes de pedagogia del cine com Cinema en curs és tentativa pertinent per a poder incorporar altra manera d'entendre la pràctica creativa als currículums i poder abordar l'audiovisual i la teòrico-pràctica del cine, com a acte de creació, amb estratègies assagístiques que possen en pràctica una pedagogia de la mirada creadora.

Considerant que l'assaig audiovisual implica un cert nivell de comprensió i de maduració d'aspectes crítics i reflexius de l'aprenentatge, contemplats al disseny curricular de l'ESO, és adient plantejar que la manera de introduir l'assaig a les aules podria fer-se a partir dels cursos de Batxillerat, de manera interdisciplinària, generant un repte i un desafiament a les tendències, possibles aillaments i vicis departamentals, proposant, per exemple, treballs filosòfico-històrics [o d'altres disciplines] d'interés social i culturals, amb respostes artístiques.

Treballar amb l'assaig audiovisual podria ser una manera de fomentar actitut creativa, donar visibilitat i fer sensibles interrogants existencials o vitals [que a sovint son un creuament d'interrogants] no sempre fàcils de traduir o expressar per l'alumnat adolescent. 
En el curs d'aquest treball, a través dels materials consultats, dels assajos visionats i de la recerca, a partir de converses i referències facilitades per amics, amigues i companys d'estudis, he trobat vies de deriva que, [considerant l'àmbit obert i complex de l'assaig audiovisual] en principi, no hagueren participat de l'exploració, però podrien haver estat. És el cas dels exemples d'algunes pràctiques en plataformes de youtube. S'han trobat micro-oportunitats presents a alguns vídeos amb un caire més pedagògic on no només trobem presents marques dels nous paradigmes: complexitat, autorreferencialitat, alussivitat als imaginaris, i consciència crítica sino també una sintomatología del futur i aspectes de fer i dir alternatius, más visuals en matèria de argumentació i difusió de continguts.

El foment de les intel.ligències intrapersonals, interpersonals, les competències consubstancials al treball cinematogràfic i el treball cooperatiu, reforcen la idoneitat dels assajos a la vida educativa. Les possibilitats de redistribuir rols, d'atendre a l'entorn i poder treballar aspectes de la vida quotidiana, fan de la reflexió assagística un eina saludablement integrable a l'aula.

En aquest sentit, pensar l'assaig com a forma oberta de reconfiguració vital i de creuament d'experiències múltiples, també com a trobada d'interrogants artístics i existencials, ens aproxima a una manera d'estar crítica i conscient exercitant la mirada, per a aprendre a veure. estimulant modalitats no sempre conscients de l'experiència i la dimensió perceptiva dels alumnes.

\section{REFERĖNCIES}

Adorno. T.W. [1962]. El ensayo como forma. Barcelona: Ariel.

Aguirre, I. [2006]. Modelos formativos en Educación Artística: Imaginando nuevas presencias para las artes en educación. Bogotá.

Aidelman, N. i De Lucas, G. [eds]. [2010]. Jean-Luc Godard. Pensar entre imágenes. Barcelona: Intermedio.

Bergala, A. [2007]. La hipótesis del cine. Pequeño tratado sobre la transmisión del cine en la escuela y fuera de ella. Barcelona: Laertes.

Català, J.M. [2014]. La estética del ensayo. La forma ensayo de Montaigne a Godard. València: Universitat de València, PUV.

Cuello Blanco, V. [2011]. Ensayo sobre el ensayo audiovisual. Cuadernos de música, Artes Visuales y Artes escénicas, 6 [2], 13-34.

Cuesta, M. [2009]. Notas sobre el ensayo. Nómadas. Revista Crítica de Ciencias Sociales i Jurídicas, 21 [1].

Esquirol, J. M. [2016]. La resistencia íntima. Ensayo de una filosofía de la proximidad. Barcelona: Acantilado.

Giroux, H. [1996]. Placeres inquietantes. Aprendiendo de la cultura popular. Barcelona: Paidós. Hernández, F. [1997]. Educación y Cultura Visual. Sevilla: MCEP. 
Weinrichter, A. [2005] Desvíos de lo real. Madrid: T\&B.

Weinrichter A.(ed.]. [2007]. La forma que piensa. Tentativas en torno al cine ensayo. Pamplona: Punto de vista. Gobierno de Navarra.

\section{WEBS CONSULTADES}

Decret 87/2015, del Consell, pel que establix el currículum i la ordenació general de Juny de 2015. Recuperat de http://www.dogv.gva.es/disposicio-consolidada?signatura=00525 4/2015\&idioma=es\&L=1\&url lista=

Llei Orgànica 8/2013, de 9 de Desembre, per a la Millora de la Qualitat Educativa [LOMQE]. Recuperat de https://www.boe.es/buscar/doc.php?id=BOE-A-2013-12886

Machado, A. (2010]. El filme-ensayo, laFuga, 11. [Fecha de consulta: 2018-05-31] Disponible en: http://2016.lafuga.cl/el-filme-ensayo/409

\section{PEL.LÍCULES ESTUDIADES}

Argos Film[Productor] i Marker, C. [director]. [1982]. Sans Soleil [film assaig]. França: Argos Film.

Cañas, M. [Productora] i Cañas, M.[directora]. [2003]. Sé villana. [La Sevilla del diablo] [film assaig]. Espanya: María Cañas. En Márgenes, recuperat de https://vimeo.com/62269731

Duque, A. [Productor] i Duque, A.[director]. [2012] Dress Rehearsal for utopia [film assaig]. Espanya: Andrés Duque.

Monsell,P. [Productora] i Monsell, P. [directora].[2014]. África 815 [film-assaig]. Espanya: Pilar Monsell.

I Jornadas Internacionales del Audiovisual Contemporáneo [JOINAC). [2007). DVD de la videograbació de les jornades. Videoteca de la Filmoteca de València. 